\title{
PATOGENESIS INFEKSI CRYPTOSPORIDIUM
}

\author{
Putu Indah Budi Apsari \\ Departemen Mikrobiologi Dan Parasitologi, \\ Fakultas Kedokteran Dan Ilmu Kesehatan Universitas Warmadewa \\ putuindah51@yahoo.com
}

\begin{abstract}
Abstrak
Cryptosporidium adalah protozoa usus yang dipublikasi pertama kali di Johns Hopkins School of Medicine sebagai penyebab Cryptosporidiosis pada tahun 1976. Beberapa aspek biologi dan interaksi alamiah Cryptosporidium dengan host masih belum jelas. Penggunaan metode molekuler sangat membantu pemahaman kita tentang biologi dan epidemiologi spesies Cryptosporidium. Hal ini termasuk peningkatan pengetahuan tentang struktur spesies dan genetik dalam populasi Cryptosporidium, peran dari berbagai rute transmisi dalam epidemiologi Cryptosporidiosis, serta penentuan genetika parasit dalam patogenesis dan presentasi klinis. Review ini bertujuan membedah aspek yang berpengaruh terhadap pathogenesis infeksi Cryptosporidium.
\end{abstract}

Keywords: Cryptosporidium, infeksi, pathogenesis

\section{Pendahuluan}

Sel epitel mukosa intestinal sangat penting dalam inisiasi respon imun mukosa pada patogen usus. Tidak hanya sebagai barier pemisah lingkungan dalam dan luar, namun sel epitel juga memproduksi berbagai macam sitokin dan kemokin sebagai respon terhadap komponen mikroba. Sebagai interaksi pertama C. parvum adalah invasi sel epitel mukosa, peristiwa yang terjadi tergantung pada daya tahan parasit dan status imun inang. (Caccio dkk, 2014)

Ookista Cryptosporidium yang tertelan oleh manusia akan mengalami eksitasi mengeluarkan sporozoit setelah mencapai lumen usus halus. Sprozoit akan melekat pada sel epitel kemudian melakukan invasi menggunakan beberapa ligand dan protein khusus. Prosen invasi ini menyebabkan pemendekan villi usus, proliferasi sel infiltrat yang berada dibawah lapisan epitel. Perlekatan sporozoit yang dimediasi ligand-reseptor memicu aktin sitoskeleton membentuk vakuola parasitoporus yang berperan dalam perkembangan parasit dan mengeluarkan efek dari inang dan sel disekitarnya. Kapsul parasitoporus membungkus tropozoit dan schizont, merupakan derivat dari mikrovilli dan menyatu dengan inang, dan apikal sitoplasma dari sel epitel kemudian dibungkus oleh membran sel inang. Sehingga organel tersebut intraseluler namun ekstrasitoplasmik. (Mekonnen dkk, 2016)

Kerusakan sel enterosit monolayer terjadi selama perusakan tight cell juction, kehilangan fungsi barier kemudian pengeluaran laktat dehidrogenase dan peningkatan laju kematian sel. Mekanisme yang menyebabkan kerusakan sel selama infeksi Cryptosporidium sampai saat ini belum diketahui, namun beberapa molekul dapat merusak jaringan secara langsung seperti fofolipase, protease, dan hemolisisn. Protease mempunyai peran penting dalam daur hidup parasit seperti fungsi mediasi degradasi protein, invasi ke sel inang, dan evasi imun inang. Aktifitas protease Cryptosporidium telah diidentifikasi pada sporozoit seperti: aminopeptidase, sistein protease, dan serine 
protease yang berimplikasi pada proses eksitasi. Identifikasi fungsi protease selama eksitasi dan pencegahan infeksi yang terjadi karena protease inhibitor menunjukkan pentingnya peran protease pada fase awal infeksi Cryptosporidium. (Caccio dkk, 2014). Apoptosis atau kematian sel terprogram terjadi sebagai respon infeksi patogen. Apoptosis sebagai defensif mekanisme dan regulasi respon inang terhadap patogen baik invasif maupun non invasif. (Deng dkk, 2004)

Penelitian menggunakan imunisasi pasif menunjukan infeksi Cryptosporidium baik in vitro maupun in vivo dapat dicegah dengan pemberian antibodi monoklonal maupun poliklonal melawan antigen permukaan sporozoit, mengindikasikan bahwa ada molekul spesifik pada permukaan sporozoit yang berperan dalam interaksi antara host dan Cryprosporidium. (Deng dkk, 2004)

\section{Ligand Cryptosporidium parvum}

Sampai saat ini sedikit data yang diketahui berkaitan dengan reseptor atau ligand yang berinteraksi antara sporozoit $C$. parvum dengan sel epitel inang.penelittian sebelumnya mengidentifikasi beberapa low-molecular weight protein pada $C$. parvum yang berperan dalam adhesi dan motilitas parasit, seperti (glycol)-proteins sporozoit termasuk GP900, galactose- $N$-acetylgalactosamine

(Gal/GalNAc)-specific lectin, gp15/40, thrombospondin-related anonymous proteins (TRAPs), CP47, dan CSL glycoprotein.(Bouzid dkk, 2013)

\section{a. GP900}

GP900 adalah glikoprotein dalam jumlah besar pada sporozoit dan merozoit $C$. parvum merupakan antigen yang menonjol dikenali oleh imunoglobulin colostral pada sapi. Dia berlokasi pada mikronema dan pada permukaan fase infasif dan berperan dalam infasi ke dalam sel epitel inang. Kloning dan sekuen analisis mengindikasikan GP900 adalah mucin-like glycoprotein yang disusun dari cysteine-rich domains dipisahkan oleh polythreonine domains dan membrane proximal $\mathrm{N}$-glycosylated core region dalam jumlah besar. Kedua tipe GP900 native maupun recombinant cysteine rich domain menghalangi invasi $C$. parvum pada level $50 \%$ picomolar dan nanomolar pada percobaan in vitro. Penelitian tersebut menunjukan GP900 berperan sebagai ligand pada reseptor sel inang. Reseptor sel inang untuk ligand GPP900 sampai saat ini belum diketahui. (Bouzid dkk, 2013)

\section{b. Gal/GalNAc-specific lectin}

Gal/GalNAc-specific lectin ditemukan pada permukaan sporozoit $C$. parvum dan mungkin memediasi perlekatan sporozoit dan sel epitel inang. Pada percobaan menggunakan kucing Gal/GalNAc eksogen menghalangi adesi sporozoit ke sel epitel kucing, yang berarti bahwa dia memediasi sporozoit melekat ke sel epitel inang. Chen dan Larusso juga mendemonstrasikan epitop glikoprotein Gal/GalNAc pada membrane apical epitel kandung empedu dan Gal/GalNAc-specific lectin memediasi perlekatan sporozoit pada permukaan sel epitel inang. (Bouzid dkk, 2013)

\section{c. $\mathrm{gp15/40}$}

gp15 dan gp40 merupakan produk pembelahan proteolitik dari protein prekursor 49-kDa, yang terekspresi pada fase intraseluler C.parvum, walaupun dikode oleh gen yang sama, mereka merupakan dua antigen yang berbeda dan berada pada lokasi yang berbeda. Glicoproteins 40 berlokasi pada kompleks apical, dan gp40 berlokasi pada permukaan dalam sporozoit. Pada penelitian ditemukan bahwa antibody monoclonal untuk gp40 dapat menetralisir infeksi $C$. parvum dan menghalangi sporozoit melekat pada sel epitel usus manusia Caco-2 cells. Epitope yang dikenali oleh antibody monoclonal gp40 mengandung residu $N$ acetylgalactosamine. Data ini berimplikasi pada protein ini merupakan molekul kunci yang terlibat pada proses perlekatan dan invasi ke sel inang. (Bouzid dkk, 2013) 


\section{d. TRAP}

Thrombospondin related adhesive protein of Cryptosporidium-1 (trap-c1) pertama kali dideskripsikan pada tahun 1998. Peneliti melakukan klon dan sekuen dari trapc1 dari $C$. parvum dengan asumsi homolog dengan antigen Eimeria, dan digambarkan mempunyai sekuen dengan intron yang berlokasi pada kromosom nomor 6, kode tersebut untuk protein $76 \mathrm{kDa}$. Dia mempunyai ortologus atau paralogus pada regio genom lain terutama pada $\mathrm{C}$. hominis dan C. muris. Protein trap-c1 memeiliki ciri khas adanya motif TRM, karakterristik dari family trombospondin, motif ini memberikan gen trap-c1 kemampuan untuk mengikat konjugat glikosulfat, yang menyusun mukosa glikokaliks yang melindungi mukosa sel epitel usus. Peneliti menempatkan protein ini pada kompleks apical pada sporozoit $C$. parvum. Semua observasi menunjukkan protein ini berperan dalam prosen invasi ke dalam sel host. Kedua protein TSP pada C.parvum yang disebut trap-2 juga dideskripsikan berlokasi pada kromosom nomor 5 dan protein $430 \mathrm{kDa}$ merupakan komponen membrane sporozoit, yang mempunyai aktivitas molekuler oksireduktase dan iron-sulfer cluster binding dan terlibat dalam proses diferensiasi sel. Perbedaan sekuen gen ini dapat membedakan spesies Cryptosporidium. (Deng dkk, 2002)

\section{e. Hemolisin $\mathrm{H} 4$}

Hemolisin $\mathrm{H} 4$ telah diidentifikasi lewat skrining ekspresi $C$. parvum pada agar darah domba. H4 memiliki urutan yang sama dengan hemolisin Escherichia enterohemorrhagic Coli O157: H7 . Fungsi $\mathrm{H} 4$ tidak diketahui, namun kemampuan untuk mengganggu membran sel menunjukkan peran dalam invasi seluler dan atau menganggu membran vacuolar, yang akan memungkinkan merozoit untuk keluar dari vakuola parasitophorous dan menyebar ke sel yang berdekatan. Protein Cryptosporidium yang lain yang menarik adalah $C$. parvum ATP-binding cassette $(\mathrm{ABC})$ gen transporter $(\mathrm{CpABC})$ yang berada dekat dengan makan organel electron-dense feeding dari vakuola parasitophorous, yang mungkin terkait dengan memenuhi kebutuhan gizi utama. Menariknya, unsur-unsur genetik ini memeiliki berbagai kesamaan dengan gen bakteri, yang menyebabkan diare sekretori. (Bouzid dkk, 2013)

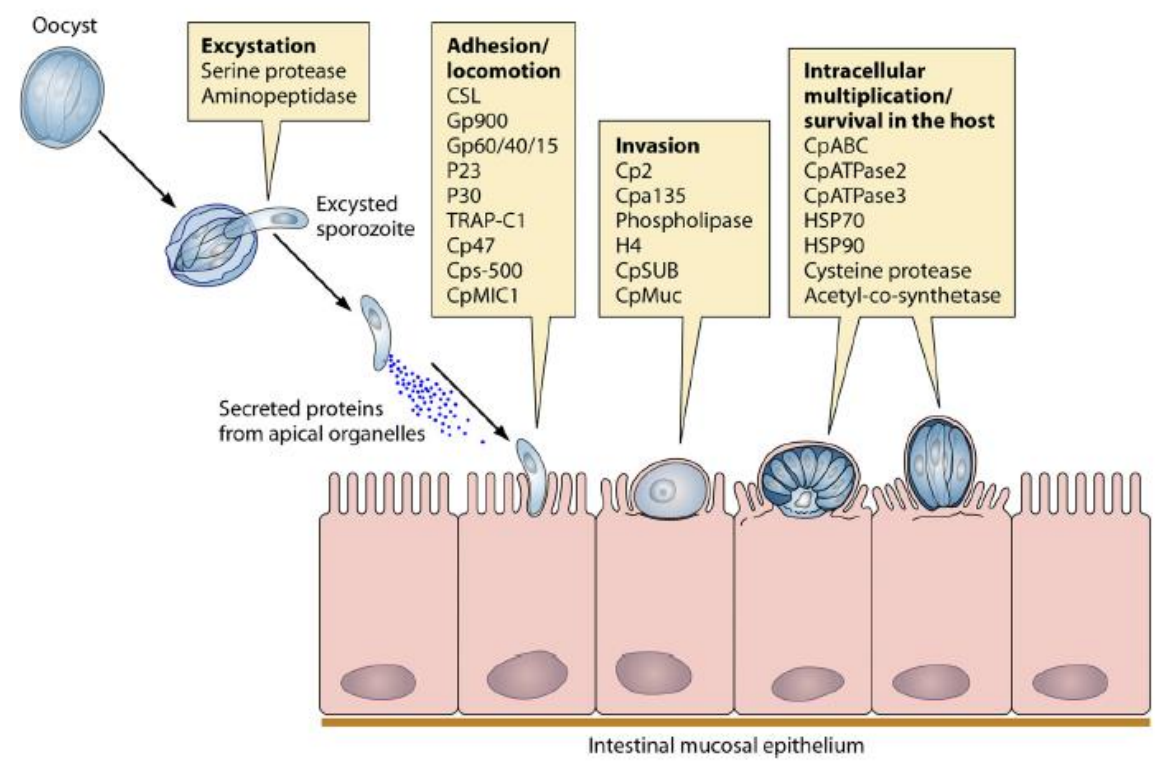

Gambar 5: Proses skematik invasi Cryotosporidium ke dalam sel epitel usus halus dan faktor virulensi yang terlibat

Sumber: http://cmr.asm.org 
Faktor Inang dan Faktor Virulensi Cryptosporidium

1. Reseptor Epitelial pada Sel Inang

a) Reseptor untuk $\mathrm{CP} 47$

Nesterenko et al melaporkan $\mathrm{CP} 47$ merupakan membrane-associated protein dari 47-kDa yang berlokasi pada ujung akhir apical sporozoit $C$. parvum, menunjukan afinitas yang kuat pada permukaan pada kedua kultur HTC-8 sel line epitel manusia dan sel ileum manusia. Aktifitas pengikatan $\mathrm{CP} 47$ ditemukan sensitive mangan, konsisten dengan penemuan yang lebih awal yang mendemonstrasikan efek inhibisi ion $\mathrm{Mn}^{2+}$ pada infeksi Crypptosporidium pada percobaan in vitro maupun in vivo. Protein tunggal dengan mobilisasi menggunakan elektroforesis $57 \mathrm{kDa}$ dimurnikan pada membrane sel HCT-8 dan sel duodenum mengunakan model tikus mengunakan CP47-Affigel. Afinitas protein ini dinetralkan dengan adanya $\mathrm{Mn}^{2+}$. data ini menunjukan protein $\mathrm{CP} 47$ pada parasit berinteraksi dengan reseptor $57-\mathrm{kDa}$ pada inang. (Deng dkk, 2004)

b) Reseptor untuk CSL glycoprotein

C. parvum circumsporozoite-like (CSL) glycoprotein merupakan 1300-kDa glycoprotein dari sporozoites and merozoites $C$. parvum yang berlokasi pada kompleks apikal. Dia diidentifikasi oleh antibody monoclonal mencegah perlekatan dan invasi sprorozoit in vivo dan memberikan perlindungan pasif melawan C. pavum. Beberapa penelitian mengkonfirmasi CSL mengantung ligand sporozoit yang memfasilitasi perlekatan dan invasi pada kultur $\mathrm{Caco}$ 2 cells. Fungsi ligand dapat diputus dengan antibody monoclonal anti-CSL. Reseptor sel inang untuk CSL salah satunya $85 \mathrm{kDa}$ protein, karena penambahan molekul ini pada isolate mengurangi pengikatannya dengan antibodi monoklonal anti-CSL Perlekaan C.parvum pada sel Caco-2 berkurang secara signifikan dengan penambahan $85-\mathrm{kDa}$ protein. Data ini menunjukan bahwa CSL merupakan ligan penting pada sporozoit $C$. parvum dan dia melekan pada reseptor $85-\mathrm{kDa}$ protein pada sel epitel inang. . (Tzipori $d k k, 2002)$

\section{Heat Shock Protein}

Protein Heat shock (Hsp) adalah family dari protein yang dikonservasi dalam jumlah besar. Mereka biasanya ditentukan oleh berat molekul yang dianalisa lewat natrium dodesil sulfatpoliakrilamida gel pada proses elektroforesis (SDS-PAGE), dengan Hsp90, HSP70, dan HSP65 menjadi famili yang paling umum. Tingkat sintesis Hsp, terutama HSP70, meningkat secara dramatis dalam kondisi stres (perubahan suhu mendadak, penurunan ketersediaan nutrisi, dan penurunan kekebalan tubuh). Fungsi Hsp sebagai kofaktor intraseluler untuk protein lain memainkan peran penting dalam interaksi antar protein dan memfasilitasi transportasi, replikasi, perakitan, biosintesis, dan sekresi protein yang baru terbentuk. Untuk Cryptosporidium, 2 jenis Hsp (HSP70 dan Hsp90) telah dijelaskan. Polimorfisme yang cukup besar dalam gen HSP70 telah diidentifikasi dan digunakan untuk tujuan genotipe. Namun, Hsp berada di bawah tekanan selektif, dan semakin banyak polimorfisme mungkin tidak mencerminkan hubungan genetik antara isolat atau subtipe. (Enemark, 2003)

\section{Respon Sel epitel terhadap Infeksi $C$. parvum.}

a) Modulasi sitoskeleton

Perlekatan dan invasi oleh parasite obligat intra seluler menginduksi penyusunan sitoskeleton pada sel inang untuk mengawali penetrasi membrane dan intrusi sitoplasma. Penggunaan aktin 
inang merupakan tema utama pataogenesis microbial dan diamati pada infeksi yang disaebabkan oleh bakteri dan parasite. Untuk pathogen protozoa, polimerisasi aktin pada parasite ditujukan untuk menyediakan motif serangan pada membrane inang dan lokalisasi intraseluler. Selama invasi Cryptosporidium dan perkembangan intraseluler,beberapa elemen sitoskeleton inang mengalami perubahan dan membentuk struktur unik pada permukaan yang dilekati oleh parasit. Pada pengujian secara in vitro menggunakan inhibitor mikrotubul dan mikrofilamen terbukti kedua orgaanel ini mempunya peran penting. (Deng dkk, 2004)

Forney et al mengamati cel signaling yang dipicu oleh $\mathrm{C}$ parvum dan terjadi remodeleing mikrotubul. Onset cepat dari aktivitas fosfolipid dan protein kinase selama perlekatan sporozoit. Sebagian phosphoinositide 3-kinase teraktivasi selama proses invasi. Aktin sel inang dan acting binding protein villin berinteraksi menginisiasi pembentukan awal vakuola parasitoporus. Pada system bilier dan intestinal rekruitmen aktin secara langsung berbatasan dengan $C$. parvum diamati menggunakan mikroskop konvokal. Pewarnaan menggunaka paloidin pada sel epitel yang terinfeksi $C$. parvum menunjukkan akumulasi filament aktin pada permukaan sel inang dengan parasite. Elliot et all membuktikan bahwa polimerisasi aktiin membutuhkan faktor protein Arp2/3, vasodilator-stimulated phosphoprotein (VASP), dan neural Wiskott Aldrich syndrome protein (NWASP). Selain itu c-Src, cytoskeletonassociated protein tyrosine kinase, dan cortactin actin-binding protein dan substrat untuk $c$-Src dirwkrut selama proses interaksi anatara sel inang dan parasit. (Deng dkk, 2004) b) Apoptosis

Apoptosis memegang peranan dalam mngeleminasi sel yang terinfeksi $C$. parvum dan mengatur respon inang terhadap melawan invasive dan noninfasif pathogen. Bertolak belakang dengan parasit, setiap patogen mempunyai cara sendiri menghadapi sistem defensif sel inang, dia mempunyai banyak cara untuk menangkal apoptosis. Chen et al perama kali mengemukakan efek sitoplasmik dari infeksi $C$. parvum, terjadi apoptosis yang luas pada sel bilier yang diinfeksi, efek sitopatik ini merukapan reaksi yang relevan dari pathogenesis kolangitis sclerosis sekunder yang diamati pada pasien AIDS dengan Cryptosporidiosis bilier. Ojcius et al mengamati terjadi kondensasi inti pada sel HCT-8 dan persentase sel apoptotic yang meningkat seiring peningkatan jumlah ookista yang digunakan untuk menginfeksi sel. McCole menyatakan $C$. parvum menginduksi apoptosis pada level sedang pada sec Caco-2 dan HCT-8, menghambat apoptosis ini selama kurang lebih 24 jam setelah invasi, dan kecepatan apoptosis pada sel intestinal sama dengan sel bilier. Percobaan lain menggunakan agen proapoptosis seperti staurosporine (inhibitor of protein kinase $C$ ), etoposide (DNA topoisomerase II inhibitor), dan 5fluorouracil (thymidinemonophosphate synthesis inhibitor). Data ini menunjukan bahwa parasite membuat strategi untuk memfasilitasi perkembangan intraseluler dan maturasi pada periode awal infeksi. Selanjutnya Chen et al menyelidiki molekul yang berperan dalam penghambatan apoptosis, bahwa Fas reseptor atau fas ligan memiliki peran menetralisir antibody. Kaspase juga berperan dalam apoptosis, penggunaan $\mathrm{z}$ VAD-fmk, kaspase inhibitor menambah jumlah sel yang terinfeksi. Nuclear factor $\mathrm{kB}$ (NF-kB) ditunjukan dapat 
menghambat apoptosis sel yang menghasilkan TNF- $\alpha$ pada beberapa percobaan. Chen et al menunjukkan aktivasi NF-kB dapat menghambat cel apoptosis yang diinduksi oleh $C$. parvum. Jadi C parvum menginduksi apoptosis juga menghambat apoptosis pada sel inang. Sel yang diinduksi adalah sel yang dipantau oleh sel yang tidak terinfeksi, untuk membatasi penyebaran. Menginduksi apoptosis pada level sedang bertujuan mencegah respon inflamasi sel inang yang berlebihan yang dapat membahayakan parasit. (Deng dkk, 2004)

c) Regulasi Sitokin Proinflamasi dan Regulasi Imun

Salah satu sitokin yang diregulasi adalah interleukin 8 (IL-8). IL-8 adalah kunci aktivasi neutrophil chemokine yang diinduksi oleh sel endothelial, epithelial cells, dan limfosit serta memegang perannan penting pada imunitas awal melawan mikroba. Ekspresinya muncul 16-24 jam setelag infeksi dan meningkat tajam 1-2 hari. Interleukin 8 mRNA juga terdeteksi pada jaringa intestinal setelah 7 hari pasca infeksi. Sitokin proinflamasi lain yang terdeteksi antara lain Gro-a, TNFa,dan RANTES (regulated upon normal $T$ cel activation and secreted) atau CCL-5. (Deng dkk, 2004)

d) Regulasi TGF- $\beta$ Transforming Growth Factor- $\beta$ )

TGF- $\beta$ merupakan sitokin antiinflamasi yang disintasis dan disekresikan oleh sel intestinal, dengan menstimulasi protein matriks ektraseluler. Dia bertugas mengatur perbaikan epitel mukosa yang rusak oleh pathogen Transforming Growth Factor $-\beta$ mRNA ditemukan pada 12 sel yang terinfeksi. Demostrasi yang dilakukan oleh beberapa peneliti menunjukan ada erbaikan barrier mukosa yang diinduksi oleh TGF- $\beta$. (Deng dkk, 2004) e) Regulasi Prostaglandin

Prostaglandin merupakan kunci promotor respon imun inang. Perubahan kloridan dan sekresi cairan meregulasi kehadiran prostaglandin memicu sekresi mucin yang dapat melindungi host dari pathogen. Prostaglandin juga bisa menurunkan regulasi sitokin inflamasi oleh makrofag. Penelitian sebelumnya menunjukan bahwa prostaglandin tergantung pada aktivitas Cyclooxygenase-1 (COX-1) dan Cox-2. (Deng dkk, 2004)

f) Regulasi Nitric Oxide (NO)

Nitric Oxide (NO) diproduksi dari arginine oleh enzim nitric oxide synthase (NOS), diketahui mempunyai efek antimikroba luas. Salah satu isoform NOS yaitu iNOS, menginduksi ekspresi sel epitel manusia, dan ditemukan entrosit meningkatkan produksi NO via iNOS dengan keberadaan IFN- $\gamma$, TNF-a dan IL$1 \alpha$. (Deng dkk, 2004)

g) Regulasi $\beta$-defensin

Alpha dan $\beta$-defensins merupakan low molecular mass antimicrobial peptide yang mempunyai peran dalam imunitas awal. Sinergi dengan lytic peptides Hecate-1, Shiva-10, dan Cecropin-b analog $S B-37$ yang mempunyai aktivitas anti mikrobial. Analisis menggunakan Ntoren Blot pada usus sapi ditemukan salah satu $\beta$-defensin yaitu enteric $\beta$ defensin, terekspresi sangat tinggi pada kripte usus halus dan kolon. Enteric $\beta$ defensin terlokalisir in situ pada sel epitel usus halus dan kolon. Enteric $\beta$-defensin berperan dalam innate imunity melawan parasit. (Deng dkk, 2004)

\section{Perubahan Morfologi Intestinal Akibat Infeksi Cryptosporidium}

Berdasarkan penemuan hitologi pataologi anatomi yang dilakukan menggunakan hewan coba oleh Abdou dkk, ditemukan bagian terminal ileum merupakan sebagai lokasi yang mengalami infeksi paling berat baik diantara 
kelompok imunosupresi maupun imunokompeten. Hal tersebut terkait dengan reseptor dan kondisi biokimia dimana parasit dapat hidup dengan suasana kaya nutrisi dan molekul-molekul yang dibutuhkan untuk hidup. Walaupun penemuan lain menyatakan bahwa parasit banyak hidup pada sambungan ileocecal. Perubahan displasia low grade diamati terjadi pada $40 \%$ subjek penelitian, dan $40 \%$ mengalami high grade displasia. Perkembangan menjadi adenoma intraepitelial juga dilaporkan terjadi pada kelompok yang ditekan mengunakan deksametason dan mengalami imunodefisiensi berat. Pada percobaan lain menggunakan tikus dengan status imunodefisiensi sangat berat dan menggunakan strain Cryptosporidium yang ganas, ditemukan terjadi Frank carcinoma, yaitu intramucosal carcinoma. Walapun paa percobaan digunakan jenis Cryptosporidium parvum yang menghasilkan displasia yang low grade namaun ini bisa menjadi prekursor untuk keganasan saluran cerna. Prevalensi Cryptosporidium meningkat sebanyak $18 \%$ pada penderita carcinoma colorectal, tumor primernya berlokasi pada sisi kiri daerah sigmoid dan colon descenden. Pada penelitian tersebut didapatkan ada hubungan antara perkembangan fase high grade displasia dengan perkembangan parasit di dalam sel intestinal. Hal ini menyatakan bahwa ada efek jumlah parasit dengan transformasi keganasan. Untuk memastikan hal ini digunakan pengujian imunohistokimia menggunakan marker cyclin D1 untuk mengidentifikasi true displasia. Cyclin D1 positif pada adenoma intestinal famili dari adenomatous polyposis syndrome dan berhubungan dengan aktifitas proliferatif dan tingkat keparahan displasia pada lesi premalignan tersebut. Keberadaan cyclin D1 dapat merupakan tanda awal karsinogenesis intestinal. (Stephens, 1999)

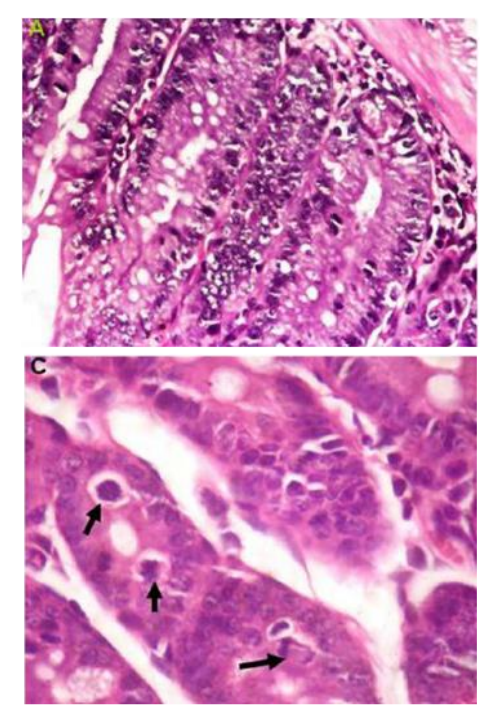

Gambar : High grade displasia pada epitel intestinal

Sumber: Elsevier, International Journal of Infectious Diseases

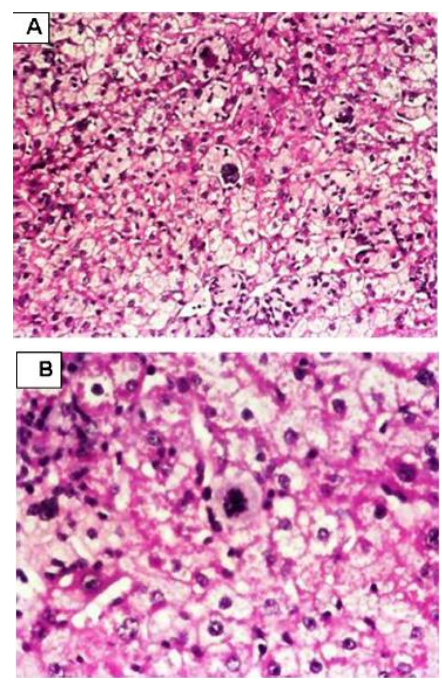

Gambar: Large cell dysplasia pada liver mencit yang terinfeksi Cryptospporidium

Sumber: Elsevier, International Journal of Infectious Diseases

\section{Kesimpulan}

Pengetahuan tentang struktur spesies dan genetik dalam populasi Cryptosporidium, peran dari berbagai rute transmisi dalam epidemiologi kriptosporidiosis, membantuk kita dalam dalam memahami patogenesis infeksi Cryptosporidium yang nantinya menting dalam diagnosis klinis, serta memutus rute transmisi 
sehingga didapatkan kualitas pengobatan pasien yang baik dan optimal.

\section{Daftar Pustaka}

Abdou Asmaa Gaber Nancy Mahmoud Harba, Amira Fathy Afifi. 2013. Assessment of Cryptosporidium parvum infection in immunocompetent and immunocompromised mice and its role in triggering intestinal dysplasia. International Journal of Infectious Diseases. Vol. 17 p.593-600

Abrahamsen Mitchell S., Thomas J. Templeton, Shinichiro Enomoto. 2004. Complete Genome Sequence of the Apicomplexan, Cryptosporidium parvum. www.sciencemag.org science vol 304.

Brescia Cristin C., Shannon M. Griffin, Michael W. Ware. 2009. Cryptosporidium Propidium Monoazide-PCR, a MoleculaR Biology-Based Technique for Genotyping of Viable Cryptosporidium Oocysts. Applied and environmental microbiology.p. 6856-6863 Vol. 75, No. 21

Bouzid Maha, Paul R. Hunter, Rachel M. Chalmers. 2013. Cryptosporidium Pathogenicity and Virulence. Clinical Microbiology Reviews. Volume 26 Number 1; p. 115-134

Caccio Simone M., Lorenza Putignani. 2014. Epidemiology of Human Cryptosporidiosis. Text Book of Cryptosporidium: Parasite and Disease. Italy. Springer-Verlag Wien p. 4476.

Coupe Stephane, Claudine Sarfati, Samia Hamane and Francis Derouin. 2005. Detection of Cryptosporidium and Identification to the Species Level by Nested PCR and Restriction Fragment Length Polymorphism. Journal of clinical microbiology, mar., p. 1017-1023 vol. 43, no. 3

Deng Mingqi, Mark S. Rutherford, Mitchell S. Abrahamsen. 2004. Host intestinal epithelial response to Cryptosporidium parvum. Advanced Drug Delivery Reviews. Vol 56. p 869- 884

Enemark H.L., V. Bille Hansen, P. Lind. 2003. Pathogenicity of Cryptosporidium parvum Evaluation of an animal infection model. Veterinary Parasitology 113 (2003) 35-57

Gatei Wangeci, Julie Greensill, Richard W. Ashford, Luis E. Cuevas. 2003. Molecular Analysis of the $18 S$ rRNA Gene of Cryptosporidium Parasites from Patients with or without Human Immunodeficiency Virus Infections Living in Kenya, Malawi, Brazil, the United Kingdom, and Vietnam. Journal of clinical microbiology. p. 14581462 vol. 41, no. 4

Guyot K, A. Follet-dumoulin, E. Lelie`vre, C. Sarfati. 2001. Molecular Characterization of Cryptosporidium Isolates Obtained from Humans in France. American Society for Microbiology. p. 3472-3480 Vol. 39, No. 10

Stephens Janet, Mary Cosyns, Michelle Jones, and Anthony Hayward. 1999. Liver and Bile Duct Pathology Following Cryptosporidium parvum Infection of Immunodeficient Mice. Hepatology Vol. 30, No. 1; p 27-35

Liu Hua, Yujuan Shen, Jianhai Yin. 2014. Prevalence and genetic characterization of Cryptosporidium, Enterocytozoon, Giardia and Cyclospora in diarrheal outpatients in china. BMC Infectious Diseases.

Rafiei Abdollah, Zahra Rashno, Alireza Samarbafzadeh. 2014. Molecular Characterization of Cryptosporidium spp. Isolated From Immunocompromised Patients and Children Microbiol. DOI: 10.5812/jjm.9183

Spano Furio, Lorenza Putignani, James McLauchlin. 1997. PCR-RFLP analysis of The Cryptosporidium Oocyst Wall Protein (COWP) gen Discriminates Between $C$ Wrairi and $C$. parvum, and between $C$. parvum isolates of human and animal origin. FEMS Microbiology Letters. Vol 150p. 209-217

Tzipori Saul, Honorine Ward. 2002. Cryptosporidiosis: biology, pathogenesis 
and disease. Microbes and Infection. Vol 4; p 1047-1058

Thompson R.C.A., M.E. Olson, G. Zhu, S. Enomoto. 2005. Cryptosporidium and Cryptosporidiosis. Advances in Parasitology. Elsevier.

Umemiya Rika, Minoru Fukuda, Kozo Fujisaki. 2005. Electron Microscopic Observation of the Invasion Process of Cryptosporidium parvum in Severe Combined immunodeficiency Mice. American Society of Parasitologists Journal Parasitology. Vol 91(5) p. 1034-1039
Widmer Giovanni and Jessica Kissinger. 2011. Comparative genomics of cryptosporidium species. Cryptosporidium research community. Journal of clinical microbiology,

Xiao Lihua, Lillian Escalante, Chunfu Yang. 1999. Phylogenetic Analysis of Cryptosporidium Parasites Based on the Small-Subunit rRNA Gene Locus. Applied and environmental microbiology. p. 15781583 Vol. 65 , No. 4 